\title{
S5ynthesis
}

International Scientific Conference of IT and Business-Related Research

\section{VIRTUELNO PREDUZETNIŠTVO: OBRAZOVANJE KAO PODRŠKA PREDUZETNIČKOJ SPREMNOSTI STUDENATA}

\section{VIRTUAL ENTREPRENEURSHIP: EDUCATION IN SUPPORT OF ENTREPRENEURIAL READINESS OF STUDENTS}

\author{
Zoran Rakićević ${ }^{1}$ Jasmina Omerbegović Bijelović ${ }^{1}$, Brankica Ljamić-Ivanović \\ ${ }^{1}$ Fakultet organizacionih nauka, Univerzitet u Beogradu, Jove Ilića 154, Beograd, Srbija \\ ${ }^{2}$ Sinhronia Beograd, Srbija
}

\begin{abstract}
Apstrakt:
Ovaj rad prikazuje značaj preduzetničkog obrazovanja na fakultetima u Srbiji na osnovu rezultata istraživanja o preduzetničkoj spremnosti studenata. Istraživanje je sprovedeno putem upitnika o stavovima studenata na osnovu pet dimenzija preduzetničke spremnosti: preduzetničke namere; sposobnost za preduzetništvo; atraktivnosti preduzetničkog zanimanja; orijentacija ka učenju; i strast prema radu. Dimenzije preduzetničke spremnosti u istraživanju su povezane sa različitim karakteristikama studenata a) fakultetsko obrazovanje (inženjersko, menadžersko); b) preduzetničko obrazovanje kroz nastavu na fakultetu i seminare o preduzetništvu; c) preduzetničko iskustvo u porodici i okruženju; d) različite socio-demografske osobine studenata. Na osnovu toga, autori rada su definisali devet istraživačkih pitanja koja su analizirana uz pomoć koeficijenta korelacije i T-testa. Uzorak istraživanja obuhvatio je 113 studenata sa različitih fakulteta u Srbiji. Najinteresantnije istraživačko pitanje odnosilo se na poređenje dve grupe studenta (inženjeri, menadžeri) i njihove preduzetničke spremnosti. Razlika između prethodno navedene dve grupe studenta je statistički dokazana na osnovu analize navedenog uzorka i predstavljena je u radu zajedno sa ostalim odgovorima na pitanja obuhvaćena ovim istraživanjem Dobijeni rezultati istraživanja ukazuju na neophodnost uvođenja virtuelnog preduzetništva kao akademskog predmeta na svim fakultetima i univerzitetima, $\mathrm{u}$ svrhu obrazovanja budućih inženjera i menadžera.
\end{abstract}

\section{Ključne reči:}

virtuelno preduzetništvo, preduzetnička spremnost, preduzetničke namere.

\section{UVOD}

Svaki preduzetnički poduhvat koji se pokreće predstavlja rezultat određene preduzetničke namere pojedinca ili grupe. Uspeh pokrenutog biznisa u velikoj meri zavisi od preduzetničkih namera budućeg preduzetnika i njegove spremnosti da se „žrtvuje” za dostizanje poslovnih ciljeva. Virtuelno preduzetništvo je način edukacije studenta iz oblasti preduzetništva i upravljanja MSP koje ima za cilj da pospeši i podrži preduzetničke namere studenta. Pod preduzetničkim namerama se podrazumevaju namere u pokretanju poslovnog poduhvata u budućnosti. Različiti autori su ispitivali preduzetničke namere i njihovu vezu sa brojnim drugim faktorima:

- De Clercq et al. (2013) su ispitivali efekat orijentacije ka učenju i strast prema radu na preduzetničke namere studenata;

- Dinis et al. (2013) i Zampetakis et al. (2011) su istraživali uticaj psiholoških karakteristika (kreativnost i emocionalna inteligencija) studenata;

\section{Abstract:}

This paper highlights the importance of entrepreneurial education at the faculties in Serbia based on the research results on entrepreneurial readiness of students. Research was conducted by means of a questionnaire examining students' opinion and attitudes regarding the five dimensions of entrepreneurial readiness: entrepreneurial intention; entrepreneurial skills; attractiveness of entrepreneurial profession; learning orientation; passion for work. This research connects the dimensions of entrepreneurial readiness with different characteristics of students: a) university education (managers, engineers); b) entrepreneurial education through lectures at the faculty and seminars on entrepreneurship; c) entrepreneurial experience in the family and close environment; d) different socio-demographic characteristics of students. Based on that, the authors defined nine research questions that are statistically analyzed using the correlation coefficient and T-test. The sample included 113 students from several faculties in Serbia. The most interesting question refers to the comparison of two groups of students (managers and engineers) according to their entrepreneurial readiness. Based on the analyzed sample of students, the difference between these two groups is statistically proven and shown in this paper, together with all other research results. The research results indicate the importance and necessity of introducing virtual entrepreneurship as an academic course at different faculties and universities for the purpose of educating future engineers and managers.

\section{Key words:}

virtual entrepreneurship, entrepreneurial readiness, entrepreneurial intention.

- Farashah i Souitaris (2013) su ispitivali uticaj obrazovanja i treninga iz oblasti preduzetništva;

- Lee et al. (2011) su pokazali uticaj radnog okruženja i zadovoljstva poslom na preduzetničke namere;

- Nabi et al. (2010) i Zhang et al. (2013) su istraživali uticaj visokog obrazovanja na preduzetničke namere.

$\mathrm{U}$ ovom radu virtuelno preduzetništvo se predstavlja kao koncept akademskog predmeta čija je uloga da doprinese boljoj edukaciji studenata u Srbiji. Celokupna ideja za organizovanjem ovakve vrste obrazovanja na nivou svih fakulteta a naročito onih inženjerskih, je proizašla iz rezultata istraživanja o preduzetničkim namerama. Nakon uvoda, u drugom delu opisuje se koncept virtuelnog preduzetništva kao akademskog predmeta. Treći deo definiše i opisuje pojmove preduzetnička spremnost i preduzetnička namera, kao i faktore, koji prema različitim autorima, mogu na njih uticati. Četvrti deo rada predstavlja sprovedeno istraživanje o spremnosti studenata u Srbiji na preduzetništvo. Peti deo razmatra rezultate istraživanja i daje odgovore na postavljena istraživačka pitanja. Na kraju, šesti deo čini rezime i zaključak rada. 


\section{VIRTUELNO PREDUZETNIŠTVO}

Preduzetništvo se definiše kao proces u kojem pojedinac sledi poslovnu priliku bez osvrtanja na resurse kojima trenutno upravlja, i kao „umetnost“ prevođenja ideje u novi poslovni poduhvat (Beringer \& Ireland, 2010, str. 30). Preduzetnici prepoznaju priliku kao nezadovoljenu tržišnu potrebu i prevode je u uspešan biznis, pokretanjem novog preduzeća da bi zadovoljili te potrebe. (Hsieh et al., 2007; Moor et al., 2008, str. 6). Prema Omerbegović-Bijelović (2010, str. 234), preduzetništvo se može definisati kao „društvena funkcija stvaranja nove vrednosti kroz kreativnu kombinaciju poslovnih resursa“. Zampetakis (2013) tvrdi da je preduzetništvo povezano sa stvaranjem nove vrednosti i da ima značajan uticaj na ekonomski razvoj i zapošljavanje. Značaj izučavanja preduzetništva se ogleda u doprinosu koje preduzetništvo ima u savremenim ekonomijama, jer doprinosi kreiranju novih radnih mesta i stvaranju nove vrednosti.

Virtuelno preduzetništvo predstavlja posebno organizovan oblik učenja i edukacije studenata iz oblasti preduzetništva i upravljanja malim i srednjim preduzećima (MSP). Kroz interaktivni rad sa nastavnikom i mentorom, studenti uče i upoznaju se sa brojnim procesima koji imaju zadatak da simuliraju realne procese i situacije u kojim se preduzetnik nalazi kada započinje i kada upravlja svojim preduzećem. Virtuelno preduzetništvo ima i za cilj da osposobi studente za njihov budući izbor u pogledu zanimanja „preduzetnik“. U zajedničkom radu studenta i mentora nastavnika, zajednički se virtuelno $\mathrm{i}$ „u učionici“ pokreće i upravlja poslovnim poduhvatom. Pored praktičnog dela upravljanja malim biznisom, studenti slušaju i teorijsku nastavu iz tematskih oblasti preduzetništva i upravljanja MSP: kreiranje i analiza poslovne ideje; preduzetnički resursi; istraživanje tržišta za poslovnu ideju; sastavljanje i analiza biznis plana i njegovih delova (opis preduzetničke ideje, tržište i marketinški deo, procesno-resursni deo, organizaciono-menadžerski deo, ekonomsko-finansijski deo, operativni deo); koraci u pokretanju virtuelnog poslovnog poduhvata (aktivnosti u osnivanju malog preduzeća kroz upoznavanje sa neophodnom dokumentacijom i administracijom); izbor tehnološkog procesa za proizvod/uslugu; izbor dobavljača sirovina; prikupljanje neophodnih resursa za pokretanje poslovnog poduhvata; intelektualna svojina u cilju zaštite preduzetnikove poslovne ideje; društveni ciljevi u poslovanju malim biznisom i društveno odgovorno poslovanje; upravljanje malim biznisom. Na ovaj način studenti interaktivno, kroz timski rad uče o fenomenu preduzetništva i prolaze obuku iz različitih oblasti koje su povezane sa osnivanjem i vođenjem preduzetničkog poduhvata.

\section{PREDUZETNIČKA SPREMNOST}

Jedna od najčešćih dilema u vezi sa preduzetnicima je: Da li se preduzetnici rađaju ili vremenom postaju? Ovo pitanje se bazira na mitu da su neki ljudi prirodno predodređeni da budu preduzetnici. Dva glavna faktora koja mogu uticati na pokretanje uspešnog poslovnog poduhvata su: preduzetnička prilika i sklonost pojedinca ka preduzetništvu. Preduzetnička prilika je povoljan skup okolnosti koji stvara potrebu za novim proizvodom, uslugom ili biznisom (Beringer \& Ireland, 2010, p 66). Souitaris et al. (2007) veruju da inspiracija za preduzetništvo dolazi od emotivne hemije između pojedinca i konkretne prilike (Zampetakis et al., 2013). Težnja ili tendencija osobe ka preduzetništvu se definiše kao preduzetnička spremnost ili preduzetnička namera (De Clercq et al., 2013). Preduzetnička namera se odnosi na nameru pokretanja preduzeća ili biznisa u budućnosti. U preduzetničkom smislu, Thompson (2009, p. 676) definiše nameru kao samo-potvrdu uverenja osobe da namerava da pokrene novi poslovni poduhvat ili svesno planira da to učini u nekom budućem trenutku. Ajzen (1991) navodi generičku definiciju namere kao „spremnost osobe da izvrši zadato ponašanje“. To znači da se preduzetnička namera i spremnost za preduzetništvo mogu smatrati i sinonimima u određenom smislu.

Različite veze između: 1) ličnih karakteristika pojedinca i faktora okruženja, i 2) preduzetničkih namera pojedinca, istražena su kod različitih autora u literaturi:

- Preduzetničko okruženje: Ljudi čiji su roditelji preduzetnici, vrlo je verovatno da i sami postanu preduzetnici (Solesvik et al., 2013). Takođe, ista mogućnost je i sa onima koji imaju poznanika preduzetnika (Beringer \& Ireland, 2010, p. 40).

- Visoko obrazovanje: Prema Nabi et al. (2010), visoko obrazovanje smanjuje verovatnoću za preduzetništvom. Što je pojedinac obrazovaniji i više specijalizovan za određenu profesiju, to postaje privlačniji drugim preduzećima i kompanijama. Preduzetnike čine ljudi koji su okrenuti više ka biznisu a manje ka obrazovanju. Suprotno tome, Zhang et al. (2013) smatraju da je veza između obrazovanja i preduzetništva pozitivna.

- Preduzetničko obrazovanje: Ovaj tip obrazovanja u detinjstvu i adolescenciji je potvrđen kao važan za kasnije preduzetničke namere (Dinis et al., 2013). Farashah (2013) i Solesvik et al. (2013) su pokazali da postoji pozitivna veza između preduzetničkog obrazovanja i preduzetničkih namera. Farashah (2013) razlikuje tri tipa preduzetničkog obrazovanja: 1) Učenje da se razume preduzetništvo kao akademska disciplina, 2) Učenje da se deluje na preduzetnički način što je karakteristično za interno preduzetništvo i 3) Učenje da bi se postao preduzetnik.

- Psihološki faktori: privlače najveću istraživačku pažnju. Glavne psihološke karakteristike koje su povezane sa preduzetničkom namerom, prema Dinis et al. (2013) su: sklonost ka riziku; samopouzdanje, i želja za dokazivanjem. Zampetakis et al. (2013) su pokazali vezu između emocionalne inteligencije studenata i njihovih preduzetničkih namera. U drugom radu, autori su uspostavili vezu između individualne kreativnosti studenata i njihovih preduzetničkih namera.

- Pol: Žene imaju manju želju da započnu sopstveni biznis nego muškarci (Lee et al., 2011; Zhang et al., 2013).

- Ekonomsko okruženje: Preduzetničke namere mogu takođe zavisiti od eksternih faktora, kao sto su postojanje neželjenog ekonomskog okruženja i nedostatak redovnih mogućnosti za zapošljavanje (De Clercq et al., 2013).

- Radno okruženje sa nepovoljnom inovacionom klimom i/ili nedostatkom tehničkih podsticaja izvrsnosti, utiče na preduzetničke namere, kroz nisko zadovoljstvo poslom (Lee et al., 2011).

- Orijentacija ka učenju i strast prema radu nisu jedino bitni za formiranje preduzetničkih namera pojedinca, već ove dve osobine podržavaju prevođenje svake preduzetničke želje i mogućnosti za pokretanjem sopstvenog biznisa u preduzetničke namere (De Clercq et al., 2013).

Preduzetnička spremnost je širi koncept od preduzetničkih namera i definiše se kao lična kompetentnost pojedinca i njegov potencijal za preduzetništvo. Sastoji se od sledećih pet karakteristika tj. dimenzija (De Clercq et al., 2013):

1) Preduzetnička namera (engl. entrepreneurial intention), namera pojedinca da pokrene novi poslovni poduhvat $\mathrm{u}$ budućnosti. 
2) Doživljena sposobnost za preduzetništvo (engl. perceived ability), potencijal sa kojim pojedinac smatra da je sposoban da postane uspešan preduzetnik.

3) Atraktivnost preduzetničkog zanimanja (engl. perceived attractiveness), sklonost pojedinca ka preduzetničkom zanimanju.

4) Orijentacija ka učenju (engl. learning orientation), spremnost pojedinca da kontinuirano unapređuje i širi svoja znanja.

5) Strast prema radu (engl. passion for work), stepen motivacije i stepen zadovoljstva poslom.

Svaka od dimenzija preduzetničke spremnosti obuhvatila je niz pitanja o stavovima studenata koja su predstavljena zajedno sa odgovorima u Tabeli 2 .

\section{ISTRAŽIVANJE}

Istraživanje o spremnosti studenata na preduzetništvo je sprovedeno u periodu od decembra 2013. do novembra 2014. godine među 113 studenata državnih i privatnih fakulteta u Srbiji. Studenti su odgovarali na dve grupe pitanja iz ankete. Prva grupa pitanja se odnosila na socio-demografske i ostale karakteristike ispitanika: pol, godine starosti, fakultet, godina studija na fakultetu, prosečna ocena na studijama, mesto življenja, da li studenti imaju preduzetnika u porodici, da li su pohađali nastavu ili seminare iz preduzetništva. Tabela 1 predstavlja frekvencije odgovora ispitanika.
Drugi deo upitnika odnosio se na pet grupa pitanja o preduzetničkoj spremnosti, definisanih kroz pet dimenzija: preduzetničke namere, sposobnost za preduzetništvo, atraktivnost preduzetničkog zanimanja, orijentacija ka učenju i strast prema radu. Ova pitanja bila su definisana kao iskazi sa odgovorima na Likert skali od 1 - „potpuno se ne slažem“ do 5 - „potpuno se slažem“ (Tabela 2). Pitanja su bila izmešana u anketnom upitniku da bi se izbegla pristrasnost studenta u davanju odgovora.

$\mathrm{Na}$ osnovu karakteristika anketiranih studenata i njihovih stavova o spremnosti na preduzetništvo, u radu su definisana sledeća istraživačka pitanja (P1-P9):

P1: Da li godine starosti studenta predodređuju njihovu preduzetnička spremnost?

P2: Da li postoji veza izmedu prosečne ocene na studijama $i$ njihove preduzetničke spremnosti?

P3: Da li pol studenta predodređuje njihovu preduzetničku spremnost?

P4: Da li se studenti iz Beograda razlikuju od studenta iz drugih gradova Srbije u pogledu preduzetničke spremnosti?

P5: Da li studenti na završnim godinama studija imaju veću preduzetničku spremnost nego studenti na nižim godinama studija?

P6: Da li se studenti inženjerstva i menadžmenta razlikuju u pogledu preduzetničke spremnosti?

P7: Da li studenti koji imaju preduzetnika u porodici imaju veći nivo preduzetničke spremnosti nego studenti koji nemaju preduzetnike u porodici?

\begin{tabular}{|c|c|c|c|}
\hline & Kategorijalne varijable & Broj $^{*}$ & Procenat[\%] \\
\hline \multirow{2}{*}{ Pol } & Muškarci & 46 & $40,7 \%$ \\
\hline & Žene & 67 & $59,3 \%$ \\
\hline \multirow{11}{*}{ Fakultet } & Fakultet organizacionih nauka & 74 & $65,5 \%$ \\
\hline & Mašinski fakultet & 8 & $7,1 \%$ \\
\hline & Ekonomski fakultet & 3 & $2,7 \%$ \\
\hline & Elektrotehnički fakultet & 3 & $2,7 \%$ \\
\hline & Tehnološko-metalurški fakultet & 3 & $2,7 \%$ \\
\hline & Arhitektonski fakultet & 2 & $1,8 \%$ \\
\hline & Fakultet dramskih umetnosti & 2 & $1,8 \%$ \\
\hline & Fakultet za poslovne studije, Megatrend univerzitet & 5 & $4,4 \%$ \\
\hline & Računarski fakultet, Univerzitet Union & 2 & $1,8 \%$ \\
\hline & Poslovni fakultet, Singidunum Univerzitet & 2 & $1,8 \%$ \\
\hline & Ostali fakulteti & 9 & $8,1 \%$ \\
\hline \multirow{3}{*}{ Obrazovanje } & Menadžment & 43 & $38,1 \%$ \\
\hline & Umetnost i humanističke nauke & 3 & $2,7 \%$ \\
\hline & Inženjerstvo & 67 & $59,3 \%$ \\
\hline \multirow{5}{*}{ Godina studija } & Prva & 2 & $1,8 \%$ \\
\hline & Druga & 18 & $15,9 \%$ \\
\hline & Treća & 33 & $29,2 \%$ \\
\hline & Četvrta & 47 & $41,6 \%$ \\
\hline & Master studije & 13 & $11,5 \%$ \\
\hline \multirow{2}{*}{ Mesto življenja } & Beograd & 68 & $60,2 \%$ \\
\hline & Ostali gradovi & 45 & $39,8 \%$ \\
\hline \multirow{2}{*}{ Preduzetnik u porodici } & $\mathrm{Da}$ & 36 & $31,9 \%$ \\
\hline & $\mathrm{Ne}$ & 77 & $68,1 \%$ \\
\hline \multirow{2}{*}{ Preduzetničko obrazovanje } & $\mathrm{Da}$ & 20 & $18,2 \%$ \\
\hline & $\mathrm{Ne}$ & 90 & $81,8 \%$ \\
\hline \multirow{2}{*}{ Seminari iz preduzetništva } & $\mathrm{Da}$ & 52 & $46 \%$ \\
\hline & $\mathrm{Ne}$ & 61 & $54 \%$ \\
\hline
\end{tabular}

Tabela 1. Kategorijalne varijable i njihove frekvencije 


\begin{tabular}{|c|c|c|}
\hline Varijable & $\begin{array}{c}\text { Srednja } \\
\text { vrednost }\end{array}$ & $\begin{array}{c}\text { Standardna } \\
\text { devijacija }\end{array}$ \\
\hline Spremnost na preduzetništvo: & 3,73 & 0,632 \\
\hline Preduzetnička namera (Likert skala 1-5): & 3,23 & 1,099 \\
\hline Verovatno ću uskoro pokrenuti sopstveni biznis & 3,32 & 1,054 \\
\hline Pripremam se da otpočnem sopstveni biznis & 3,14 & 1,238 \\
\hline Sposobnost za preduzetništvo (Likert skala 1-5): & 3,34 & 0,917 \\
\hline Potpuno mi je izvodljivo da otpočnem i samostalni posao. & 3,03 & 1,022 \\
\hline Osećam se sigurnim da ću moći da otpočnem sopstveni posao ukoliko to budem želeo. & 3,65 & 1,024 \\
\hline Atraktivnost preduzetničkog zanimanja (Likert skala 1-5): & 3,80 & 1,114 \\
\hline Imam jaku želju da otpočnem svoj biznis. & 3,80 & 1,189 \\
\hline Imam jaku potrebu za samo-zapošljavanjem. Moja želja je da imam sopstvenu firmu. & 3,81 & 1,151 \\
\hline Orijentacija ka učenju (Likert skala 1-5): & 4,41 & 0,476 \\
\hline Često čitam (članke, knjige, pregledam internet) da bih pojačao sopstvene sposobnosti. & 4,42 & 0,729 \\
\hline Često tražim prilike da razvijem nove veštine i znanja. & 4,50 & 0,709 \\
\hline Za mene je razvoj sopstvenih sposobnosti dovoljno važan razlog da preuzmem neki rizik & 4,25 & 0,829 \\
\hline Uživam u izazovnim zadacima koji mi omogućavaju usvajanje novih veština. & 4,41 & 0,650 \\
\hline Volim da sam uključen/na u poslove koji zahtevaju visok nivo sposobnosti i talenta. & 4,42 & 0,624 \\
\hline Sviđaju mi se izazovni zadaci iz kojih mogu mnogo da naučim & 4,50 & 0,614 \\
\hline Strast prema radu (Likert skala $1-5)$ : & 3,90 & 0,546 \\
\hline Veliki deo mog životnog zadovoljstva potiče od rada. Volim da radim. & 4,15 & 0,759 \\
\hline Dosta postižem zato što sam istrajan u radu. & 4,19 & 0,739 \\
\hline Ponekad poželim da radim više nego što trenutno radim. & 3,86 & 1,068 \\
\hline Radujem se povratku obavezama kada sam daleko od njih. & 3,41 & 1,023 \\
\hline
\end{tabular}

Tabela 2. Deskriptivna statistika varijabli koje mere preduzetničku spremnost

P8: Da li studenti koji su pohađali nastavu na fakultetu iz preduzetništva imaju veći nivo preduzetničke spremnosti i izraženije preduzetničke namere?

P9: Da li studenti koji su pokazali stvarnu zainteresovanost za preduzetništvo (pohađanjem seminara iz preduzetništva) imaju veći nivo preduzetničke spremnosti i viši nivo preduzetničkih namera?

Za pronalaženje odgovora na prethodno definisana istraživačka pitanja, korišćene su tehnike statističkog zaključivanja (koeficijent korelacije, T-test). Rezultati istraživanja i odgovori na definisan istraživačka pitanja (P1-P9), predstavljeni su u narednom poglavlju.

\section{REZULTATI I DISKUSIJA}

Podaci iz ispitivanja su statistički analizirani uz pomoć statističkog softvera za obradu podataka (PASW Statistics - SPSS 18). Deskriptivna statistika varijabli, iz drugog dela upitnika, koja meri pet dimenzija spremnosti studenata na preduzetništvo prikazana je u Tabeli 2 . Srednja vrednost promenljive „Spremnost na preduzetništvo" u celom uzorku iznosi, 3,73 (na skali od 1-5). U okviru toga, srednje vrednosti za pet dimenzija su sledeće: Preduzetničke namere (3,23); Sposobnost za preduzetništvo (3,34); Atraktivnost preduzetničkog zanimanja $(3,80)$; Orijentacija ka učenju $(4,41)$; Strast prema radu $(3,90)$. Ukupna vrednost za promenljivu spremnost na preduzetništvo (3.73) je izračunata kao prosek vrednosti prethodno navedenih pet dimenzija, sa jednakom težinom i značajnošću. Razmatranje različitih koeficijenata značajnosti za pet dimenzija preduzetničke spremnosti može se istražiti u nekom budućem radu.

Naredne analize (Tabele 3-5) daju odgovore na istraživačka pitanja (P1-P9).
P1: Da li godine starosti studenta predodređuju njihovu preduzetničku spremnost?

Posmatrajući vrednosti Personovog koeficijenta korelacije iz Tabele 3 , koje nisu bile statistički značajne $(\mathrm{p}<0.05)$ i čija vrednost je bliska nuli, nije moguće dokazati postojanje relacije po kojoj godine starosti studenta predodređuju spremnost na preduzetništvo. Takođe, godine starosti studenta nisu u vezi ni sa ostalih 5 dimenzija preduzetničke spremnosti (preduzetničke namere, sposobnost za preduzetništvo, atraktivnosti preduzetništva, orijentacija ka učenju, strast prema radu).

P2: Da li postoji veza između prosečne ocene na studijama studenata i njihove spremnosti na preduzetništvo?

$\mathrm{Na}$ osnovu rezultata navedenih u Tabeli 3, nije dobijena statistički značajna korelacija između prosečne ocene na studijama i spremnosti studenata na preduzetništvo. Vrlo je interesantno da prosečna ocena na studijama, prema uzorku ispitivanja, ima koeficijent korelaciji blizak nuli sa varijablom koja meri orijentaciju ka učenju.

P3: Da li pol studenata predodređuje njihovu preduzetničku spremnost?

$\mathrm{Na}$ osnovu rezultata ispitivanja koji su dati u Tabeli 3 i dobijeni statističkim poređenjem dve grupe studenata sa T-testom, ne postoji statistički značajna razlika u pogledu njihove spremnosti na preduzetništvo. Jedina ispoljena razlika $(\Delta 0.61$, $\mathrm{p}<0.05)$ bila je u dimenziji koja meri preduzetničke namere studenata u odnosu na studentkinje (studenti su pokazali izraženije preduzetničke namere od studentkinja).

P4: Da li se studenti iz Beograda razlikuju od studenta iz drugih gradova Srbije u pogledu nivoa spremnosti na preduzetništvo?

Ovo istraživačko pitanje postavili smo da bi smo utvrdili da li Beograd, kao glavni grad Srbije i ujedno njen najrazvijeni deo, daje više preduzetničkih mogućnosti i stvara više želje za 
Koeficijent korelacije

Srednja vrednost (T-test)

\begin{tabular}{|c|c|c|c|c|}
\hline \multirow{3}{*}{ Varijable: } & \multicolumn{2}{|c|}{ Koeficijent korelacije } & \multirow{2}{*}{\multicolumn{2}{|c|}{$\begin{array}{c}\text { Srednja vrednost (T-test) } \\
\text { Pol studenata }\end{array}$}} \\
\hline & \multirow{2}{*}{ Godine } & \multirow{2}{*}{ Prosek ocena } & & \\
\hline & & & Muški $\mathrm{N}=46$ & Ženski N $=67$ \\
\hline (S) Spremnost na preduzetništvo & -0.007 & -0.120 & 3,86 & 3,64 \\
\hline (1) Preduzetničke namere & 0.053 & -0.110 & $3,59^{*}$ & $2,98^{*}$ \\
\hline (2) Sposobnost za preduzetništvo & -0.057 & $-0.202^{*}$ & 3,53 & 3,21 \\
\hline (3) Atraktivnost preduzetništva & -0.094 & -0.168 & 4,01 & 3,66 \\
\hline (4) Orijentacija ka učenju & 0.078 & 0.067 & 4,42 & 4,41 \\
\hline (5) Strast prema radu & 0.037 & 0.036 & 3,83 & 3,95 \\
\hline
\end{tabular}

Tabela 3. Preduzetnička spremnost i godine starosti, prosečna ocena i pol studenata

\begin{tabular}{lcccccc}
\hline \multirow{2}{*}{$\begin{array}{c}\text { Varijable i njihove } \\
\text { srednje vrednosti }\end{array}$} & \multicolumn{2}{c}{ Mesto } & \multicolumn{2}{c}{ Godina studija } & \multicolumn{2}{c}{ Vrsta obrazovanja } \\
\cline { 2 - 7 } & $\begin{array}{c}\text { Beograd } \\
\mathrm{N}=68\end{array}$ & $\begin{array}{c}\text { Ostali gradovi } \\
\mathrm{N}=45\end{array}$ & $\begin{array}{c}\text { IV i Master } \\
\mathrm{N}=60\end{array}$ & $\begin{array}{c}\text { I,II,III } \\
\mathrm{N}=53\end{array}$ & $\begin{array}{c}\text { Menadžersko } \\
\mathrm{N}=43\end{array}$ & $\begin{array}{c}\text { Inženjersko } \\
\mathrm{N}=67\end{array}$ \\
\hline (S) Spremnost na preduzetništvo & 3.77 & 3.67 & 3,63 & 3,85 & $3,98^{* *}$ & $3,53^{* *}$ \\
\hline (1) Preduzetničke namere & 3.37 & 3.01 & 3,13 & 3,35 & $3,56^{* *}$ & $2,98^{* *}$ \\
\hline (2) Sposobnost za preduzetništvo & 3.43 & 3.20 & $3,18^{*}$ & $3,53^{*}$ & $3,58^{*}$ & $3,15^{*}$ \\
\hline (3) Atraktivnost preduzetništva & 3.85 & 3.72 & $3,54^{* *}$ & $4,10^{* *}$ & $4,21^{* *}$ & $3,50^{* *}$ \\
\hline (4) Orijentacija ka učenju & 4.38 & 4.46 & 4,40 & 4,43 & $4,53^{*}$ & $4,32^{*}$ \\
\hline (5) Strast prema radu & 3.88 & 3.93 & 3,90 & 3,89 & $4,02^{*}$ & $3,79^{*}$ \\
\hline Statistička značajnost: & & & ${ }^{*} \mathrm{p}<0,05$ (T - test); ${ }^{* *} \mathrm{p}<0,01$ (T - test) & &
\end{tabular}

Tabela 4. Spremnosti na preduzetništvo i mesto, godina studija, vrsta obrazovanja studenata

pokretanjem sopstvenog biznisa. Sa druge strane može se postaviti i suprotna pretpostavka, da li pojedini slabo razvijeni delovi Srbije više stimulišu ljude na preduzetničku aktivnost i samozapošljavanje kao jedini način opstanka i ekonomske egzistencije. U tom smislu posmatrane su dve grupe: studenti iz Beograda, i studenti koji su iz drugih delova i gradova Srbije. U analizi je korišćen statistički t-test a rezultati su predstavljeni u Tabeli 4. U rezultatima se ne primećuje statistički značajna razlika u spremnosti na preduzetništvo između dve grupe studenata. Takođe, razlika ne postoji ni prema pojedinačnih pet dimenzija spremnosti na preduzetništvo (preduzetnička namera, sposobnost za preduzetništvo, atraktivnosti preduzetništva, orijentacija ka učenju, strast prema radu).

P5: Da li studenti na završnim godinama studija imaju veću spremnost na preduzetništvo nego studenti na nižim godinama studija?

Ovo istraživačko pitanje treba da ispita pretpostavku da li studenti završnih godina studija (IV godina ili master), koji su položili veći deo ispita na studijama i sami tim razmišljaju o svom budućem zaposlenju, imaju veći nivo spremnosti na preduzetništvo od studenata koji su na nižim godinama studija i koji su pre orijentisani ka učenju i polaganju ispita. $U$ tom smislu studenti su bili podeljeni u dve grupe (Tabela 4). Prvu grupu su činili studenti na četvrtoj godini i na master studijama, a drugu grupu, studenti na nižim godinama studija (I, II, III). Ove dve grupe su upoređene prema spremnosti na preduzetništvo, a u okviru toga i pojedinačno prema svih pet dimenzija (preduzetnička namera, sposobnost za preduzetništvo, atraktivnosti preduzetništva, orijentacija ka učenju, strast prema radu). Posmatrajući ukupni rezultat na skali spremnosti na preduzetništvo, nije dobijena statistički značajna razlika između ove dve grupe studenata, pa se ne može pokazati da su studenti završnih godina studija spremniji na preduzetništvo. Međutim, interesantan rezultat, u ovoj analizi, je da studenti završnih godina imaju manji stepen sposobnosti za preduzetništvo $(\mathrm{p}<0.05)$ i niži nivo atraktivnosti preduzetništva $(\mathrm{p}<0.01)$ u odnosu na studente koji nisu blizu kraja svojih studija.
P6: Da li se studenti inženjerstva i menadžmenta razlikuju u pogledu spremnosti na preduzetništvo?

Uzorak istraživanja je obuhvatio dve velike grupe studenata (Tabela 1):

- Studente fakulteta za menadžment (Fakultet organizacionih nauka - studijski program menadžment i organizacija; Fakultet za ekonomiju, Fakultet za biznis, itd.) i;

- Studente inženjerskih fakulteta (Fakultet organizacionih nauka - studijski program za informacione sisteme i tehnologije, Mašinski fakultet, Elektrotehnički fakultet, Tehnološko-metalurški fakultet, Računarski fakultet).

Ove dve grupe studenata upoređene su u pogledu njihove spremnosti na preduzetništvo i pojedinačno kroz pet dimenzija. Rezultati međusobnog poređenja putem T-testa (Tabela 4), pokazali su statistički značajnu razliku između studenata menadžmenta i studenata inženjerstva u pogledu spremnosti na preduzetništvo. Preciznije, studenti sa fakulteta za menadžment pokazuju veću spremnost na preduzetništvo od studenata sa inženjerskih fakulteta, a razlika između srednjih vrednosti spremnosti na preduzetništvo je iznosila $\Delta 0,45$ ( $\mathrm{p}<0.01)$. Ukoliko dve grupe studenata uporedimo prema ostalih pet dimenzija, statistički značajne razlike u korist studenata menadžmenta su sledeće: preduzetničke namere $(\Delta 0,58 ; \mathrm{p}<0.01)$; sposobnost za preduzetništvo $(\Delta 0.43 ; \mathrm{p}<0.05)$; atraktivnost preduzetništva $(\Delta 0.71 ; \mathrm{p}<0.01)$; orijentacija ka učenju $(\Delta 0.21 ; \mathrm{p}<0.05)$; strast prema radu $(\Delta 0.23 ; \mathrm{p}<0.05)$. Najveća razlika među ovim grupe je u dimenzijama atraktivnost preduzetništva i preduzetničke namere, dok je najmanja razlika u pogledu orijentacije ka učenju i strasti za radom. Na osnovu ovog rezultata može se reći da studenti menadžmenta imaju veću spremnost na preduzetništvo od studenata inženjerstva i da se ta razlika najviše odnosi na preduzetničke namere $\mathrm{i}$ atraktivnost preduzetničkog zanimanja.

P7: Da li studenti koji imaju preduzetnika u porodici imaju veći nivo spremnosti na preduzetništvo nego studenti koji nemaju preduzetnike u porodici? 


\begin{tabular}{|c|c|c|c|c|c|c|}
\hline \multirow[b]{2}{*}{ Varijable i njihove srednje vrednosti } & \multicolumn{2}{|c|}{ Preduzetnik u porodici } & \multicolumn{2}{|c|}{ Nastava iz preduzetništva } & \multicolumn{2}{|c|}{ Seminar iz preduzetništva } \\
\hline & $\begin{array}{c}\mathrm{Da} \\
\mathrm{N}=36\end{array}$ & $\begin{array}{c}\mathrm{Ne} \\
\mathrm{N}=77\end{array}$ & $\begin{array}{c}\mathrm{Da} \\
\mathrm{N}=20\end{array}$ & $\begin{array}{c}\mathrm{Ne} \\
\mathrm{N}=90\end{array}$ & $\begin{array}{c}\mathrm{Da} \\
\mathrm{N}=52\end{array}$ & $\begin{array}{c}\mathrm{Ne} \\
\mathrm{N}=21\end{array}$ \\
\hline (S) Spremnost na preduzetništvo & 3,88 & 3,66 & 3,80 & 3,71 & $4,07^{* *}$ & $3,45^{\star *}$ \\
\hline (1) Preduzetničke namere & 3,50 & 3,10 & 3,55 & 3,15 & $3,78^{\star *}$ & $2,76^{\star *}$ \\
\hline (2) Sposobnost za preduzetništvo & $3,67^{\star *}$ & $3,19^{* *}$ & 3,32 & 3,35 & $3,69^{* *}$ & $3,04^{\star *}$ \\
\hline (3) Atraktivnost preduzetništva & 4,00 & 3,71 & 4,03 & 3,74 & $4,29^{\star *}$ & $3,38^{\star *}$ \\
\hline (4) Orijentacija ka učenju & 4,43 & 4,40 & 4,47 & 4,39 & $4,59^{* *}$ & $4,26^{\star *}$ \\
\hline (5) Strast prema radu & 3,87 & 3,92 & 3,84 & 3,93 & $4,02^{*}$ & $3,80^{*}$ \\
\hline Statistička značajnost: & & & ${ }^{* *} \mathrm{p}<0$ & $<0,05$ & & \\
\hline
\end{tabular}

Tabela 5. Spremnost na preduzetništvo i preduzetništvo u porodici, nastava i seminari

Ovo istraživačko pitanje postavljano je u skladu sa shvatanjima da na preduzetništvo pored ličnih karakteristika pojedinca, mogu uticati i njegovo okruženje tj. pozitivni primeri preduzetničke prakse iz okruženja (npr. porodice). U istraživanju studente smo pitali da li imaju preduzetnika u porodici. Na osnovu jednostavnog odgovora $(\mathrm{Da} / \mathrm{Ne})$, studenti su bili podeljeni u dve grupe i one su analizirane (kroz T-test) prema spremnosti na preduzetništvo i ostalih pet dimenzija. Rezultati predstavljeni u Tabeli 5, pokazuju da ne postoji statistički značajna razlika u spremnosti na preduzetništvo $(\Delta 0,22 ; \mathrm{p}>0.05)$. Poređenjem ovih grupa prema svih pet dimenzija: preduzetničke namere, sposobnost za preduzetništvo, atraktivnost preduzetništva, orijentacija ka učenju i strast prema radu, dala je samo statistički značajnu razliku $(\Delta 0.48 ; \mathrm{p}<0.01)$ prema sposobnosti za preduzetništvo. Na osnovu ovog rezultata može se jedino dokazati da preduzetničko okruženje studenta utiče na njegovu sposobnost za preduzetništvo.

P8: Da li studenti koji su pohadali nastavu na fakultetu iz preduzetništva imaju veći nivo preduzetničke spremnosti i izraženije preduzetničke namere?

$\mathrm{Na}$ osnovu pitanja iz upitnika o pohađanju nastave iz preduzetništva, studenti su prema njihovim jednostavnim odgovori$\mathrm{ma}(\mathrm{Da} / \mathrm{Ne})$ razvrstani u dve grupe i analizirani (putem T-testa) po spremnosti na preduzetništvo. Poređenjem dve grupe (Tabela 5) nije pokazana statistički značajna razlika $(\Delta 0,09 ; \mathrm{p}>0.05)$. Posmatranjem svih pet dimenzija, postoji izraženija razlika između dve grupe studenata u preduzetničkim namerama $(\Delta 0,40)$ i atraktivnosti preduzetničkog zanimanja $(\Delta 0,29)$ ali ove dve razlike nisu bile statistički značajne ( $\mathrm{p}>0.05)$ što je verovatno posledica nejednakosti grupa studenta $(\mathrm{N}=20$ vs. $\mathrm{N}=90)$ koje su upoređene. Razlika može nagovestiti efekat obrazovanja iz oblasti preduzetništva na preduzetničke namere i atraktivnosti preduzetničkog zanimanja, koji se mora ponovo proveriti na uravnoteženim grupama.

P9: Da li studenti koji su pokazali stvarnu zainteresovanost za preduzetništvo (pohađanjem seminara iz preduzetništva) imaju veći nivo preduzetničke spremnosti $i$ viši nivo preduzetničkih namera?

Pored prethodne analize o formalnoj edukaciji kroz nastavu iz preduzetništva, ispitivan je i uticaj neformalnog obrazovanja (seminari, treninzi) iz preduzetništva na preduzetničku spremnost studenata i njihove preduzetničke namere. Razlog tome je što studenti kroz pohađanje seminara i treninga pokazuju njihovu stvarnu zainteresovanost i želju za sticanjem dodatnih znanja i informacija za oblast preduzetništva, što ne mora biti slučaj sa formalnom nastavom koja je najčešće obaveza. Takođe, edukativni sadržaj seminara je najčešće orijentisan na praktična znanja. Studenti iz uzorka su međusobno razvrstani u dve grupe, u zavisnosti od toga da li su pohađali seminare iz preduzetništva ili ne. Rezultati su predstavljeni u tabeli 5. Pokazano je da studenti koji su pohađali seminare iz preduzetništva imaju veći nivo spremnosti na preduzetništvo (razlika između srednjih vrednosti je iznosila $\Delta 0.62 ; \mathrm{p}<0.01$ ). Razlike između dve grupe studenata poređenjem kroz pet dimenzija bile su takođe statistički značajne: preduzetničke namere $(\Delta 1,02 ; \mathrm{p}<0,01)$, sposobnost za preduzetništvo $(\Delta 0,65 ; \mathrm{p}<0,01)$, atraktivnost preduzetništva $(\Delta 0,91 ; \mathrm{p}<0,01)$, orijentacija ka učenju $(\Delta 0,33$; $\mathrm{p}<0,01)$ i strast prema radu $(\Delta 0,22 ; \mathrm{p}<0,05)$. Ovi rezultati pokazuju da studenti koji su ispoljili stvarnu zainteresovanost za preduzetništvo, pohađanjem seminara, imaju veću spremnost na preduzetništvo. Shodno tome zaključuje se da neformalno obrazovanje iz preduzetništva može povećati sklonost ka preduzetništvu.

Na kraju, dobijeni rezultati istraživanja: 1) statistički značajni uticaj vrste obrazovanja (inženjersko i menadžersko) na preduzetničku spremnost; 2) statistički značajan uticaj neformalnog obrazovanja u vidu seminara i treninga iz preduzetništva na preduzetničku spremnost; sugerišu na neophodnost uvođenja akademskog predmeta iz preduzetništva na fakultetima, posebno onim inženjerskim.

\section{REZIME}

$\mathrm{U}$ ovom radu autori su kroz istraživanje preduzetničke spremnosti studenata u Srbiji, ukazali na neophodnost organizovanja akademskog predmeta „virtuelno preduzetništvo“ na fakultetima. U istraživanju analizirane su različite grupe studenata sa idejom da se proveri veza između pojedinih karakteristika studenata i njihove spremnosti na preduzetništvo, koja je merena kroz pet dimenzija: preduzetničke namere, sposobnost za preduzetništvo, atraktivnost preduzetničkog zanimanja, orijentacija ka učenju, i strast za radom. Ispitivane karakteristike studenata bile su: pol, godine života, godina studija, mesto prebivališta, prosečna ocena na studijama, profil obrazovanja (menadžersko i inženjersko), preduzetničko okruženje studenta (preduzetnik u porodici), obrazovanje iz preduzetništva (nastava na studijama, pohađanje seminara). Sve prethodno navedene karakteristike predstavljale su varijable koje su analizirane $\mathrm{u}$ istraživačkim pitanjima (P1-P9) putem statističkih metoda (koeficijent korelacije, T-test). Najinteresantniji rezultat analize je pokazao da studenti menadžmenta imaju veću preduzetničku spremnost i izraženije preduzetničke namere za pokretanje sopstvenog poslovnog poduhvata u odnosu na studente inženjerstva. Ovaj rezultat može poslužiti kao dokaz opravdanosti promovisanja preduzetništva među studentima tehničkih i inženjerskih fakulteta koje će imati za cilj da poduče kreativne i inovativne studente kako da pokrenu sopstveni poslovni poduhvat koji je zasnovan na njihovim inženjerskim idejama. Navedene aktivnosti u edukaciji inženjera i budućih preduzetnika mogu imati snažan uticaj na ekonomski razvoj države, kroz promociju preduzetničke ekonomije. 


\section{LITERATURA}

Ajzen, I. (1991). The theory of planned behaviour. Organizational behaviour and human decision processes, 50(2), 179-211.

Barringer, B. R., \& Ireland, R. D. (2010). Entrepreneurship: Successfully launching new ventures. New Yersey: Pearson Education. ISBN: 978-0-13-8155808-8

Briggs, S. R., \& Cheek, J. M. (1986). The role of factor analysis in the development and evaluation of personality scales. Journal of personality, 54(1), 106-148.

De Clercq, D., Honig, B., \& Martin, B. (2013). The roles of learning orientation and passion for work in the formation of entrepreneurial intention. International Small Business Journal, 31(6), 652-676.

DeVellis, R. F. (2011). Scale development: Theory and applications. London: SAGE.

Dinis, A., Paço, A. F., Ferreira, J., Raposo, M., \& Rodrigues, R. G. (2013). Psychological characteristics and entrepreneurial intentions among secondary students. Education + Training, 55(8/9), 763-780.

Farashah, A. D. (2013). The process of impact of entrepreneurship education and training on entrepreneurship perception and intention: Study of educational system of Iran. Education + Training, 55 (8/9), 868-885.

Hsieh, C., Nickerson, J. A., \& Zenger, T. R. (2007). Opportunity discovery, problem solving and a theory of the entrepreneurial firm. Journal of Management Studies, 44(7), 12551277.

Lee, L., Wong, P., Foo, M., \& Leung, A. (2011). Entrepreneurial intentions: the influence of organizational and individual factors. Journal of Business Venturing, 26(1), 124-136.

Nabi, G., Holden, R., \& Walmsley, A. (2010). Entrepreneurial intentions among students: towards a re-focused research agenda. Journal of Small Business and Enterprise Development, 17(4), 537-551.
Moore, C. W., \& Longenecker, J. G. (2008). Managing small business: An entrepreneurial emphasis. Australia: South-Western/Cengage Learning.

Omerbegović-Bijelović, J. (2010). Osnove operacionog menadžmenta. Beograd: Fakultet organizacionih nauka.

Solesvik, M., Westhead, P., Matlay, H., \& Parsyak, V. N. (2013). Entrepreneurial assets and mindsets: benefit from university entrepreneurship education investment. Education + Training, 55(8/9), 748-762. DOI: 10.1108/ET-06-2013-0075

Souitaris, V., Zerbinati, S., \& Al-Laham, A. (2007). Do entrepreneurship programmes raise entrepreneurial intention of science and engineering students? The effect of learning, inspiration and resources. Journal of Business Venturing, 22(4), 566-591.

Tang, L., \& Koveos, P. E. (2004). Venture entrepreneurship, innovation entrepreneurship, and economic growth. Journal of Developmental Entrepreneurship, 9(2), 161-171.

Thompson, E. R. (2009). Individual entrepreneurial intent: Construct clarification and development of an internationally reliable metric. Entrepreneurship Theory and Practice, 33(3), 669-694.

Zampetakis, L. A., Gotsi, M., Andriopoulos, C., \& Moustakis, V. (2011). Creativity and entrepreneurial intention in young people Empirical insights from business school students. The International Journal of Entrepreneurship and Innovation, 12(3), 189-199.

Zampetakis, L. A., Kafetsios, K., \& Moustakis, V. (2013). The role of students' anticipated emotions in enterpreneurial intentions, IX Symposium of business and academics - SPIN 2013, 5-6 November, Belgrade, Serbia, 179-188.

Zhang, Y., Duijsters, G., \& Cloodt, M. (2013).The role of entrepreneurship education as a predictor of university students' entrepreneurial intention. International Entrepreneurship and Management Journal. DOI: 10.1007/s11365-0120246-z. 